Carnegie Institution of Washington has for five years furnished the funds necessary for the preparation of the manuscript and for the publishing of the tables." He also acknowledges gratefully sufficient temporary relief from academic work in the University of California to afford opportunity to devote more of his time to the arduous task of most careful proof-reading, for errors in such work are not suggested by the context, and the author wisely observes that "the value of a factor table depends chiefly on its freedom from errors."

The introduction includes a valuable list of corrections to earlier extensive tables and directs attention to "the manuscripts of Kulik which were placed in charge of the Vienna Royal Academy in 1867. These tables were said to give the smallest factor of all numbers not divisible by 2,3 or 5 up to the limit of one hundred million!" The author of the present table saw only the first one of the six volumes of Kulik's manuscript, and furnishes a rather extensive list of errata in the tenth million. He also includes, in the introduction, a short historical account of the earlier factor tables as well as some remarks on the methods of constructing such tables. In every way the present table appears to deserve a very high place among the American mathematical publications of permanent value, and both the author and the Carnegie Institution have rendered a great service not only to the mathematical public but also to many who make only occasional use of mathematics.

\section{G. A. Miller}

\section{UNIVERSITY OF ILLINOIS}

\section{SHACKLETON'S CONTRIBUTION TO BIOGEOGRAPHY}

IT has long been surmised that certain south polar lands may have one time connected several of the main biogeographic regions of the earth. Wilkes Land, South Victoria Land and Graham Land, with other near-by lands more recently named, have been conceived as forming a continent, which in times past may have stretched its shores to connections with the other continents of the southern hemisphere. Shackleton's recent work in Antarctica has now placed the existence of that continent in the realm of fact. Surmise has given way to certainty. We are now in position to deduce certain conclusions from its existence and the known conditions pertaining to it. In the hope of stimulating discussion of the general subject by those more versed in paleogeographic data than myself, I venture to state the following aspects of Shackleton's discoveries as they appear to the student of geographical distribution.

During past geologic ages, with the exception of certain relatively brief intervals of change, Antarctica has, in common with the rest of the globe, enjoyed comparative freedom from ice, excepting only the presence of alpine glaciers, and been blessed with an equable temperature. In those days the wide-stretching south polar land comprised an immense continent whose thousands of miles of extent were for the most part quickened by a mild climate and populated with an abundant life. Here during Paleozoic, Mesozoic and Tertiary time was a wonderfully rich territory, its resources now practically lost to us under an all-pervading ice-sheet. Shackleton's party found evidence of extensive coal deposits, including remains of forested areas, indicating an abundant flora and fauna. Let us see what light the former existence of such favorable biotic conditions throws on the present distribution of life with reference to Australia, South America and Africa.

Australia and New Zealand, occupying approximately longitude $110^{\circ}$ to $180^{\circ}$ east from Greenwich, are almost opposite the southern extremity of South America, which is about longitude $70^{\circ}$ west from Greenwich. The southern limits of Australia and New Zealand are in latitude $40^{\circ}$ to $50^{\circ}$ south, those of South America in latitude $55^{\circ}$ south. Thus there intervenes between these present land divisions an actual distance of only $75^{\circ}$ to $85^{\circ}$ by way of the south pole. The straight-away line between the centers of the two masses passes well to one side of the pole, and the intervening distance between their southern limits, but practically across the heart of the south polar region, may be roughly stated as 4,500 geographic miles. The southern ocean soundings so far made reveal shallow depths, or epi- 
continental seas, between the Australian-New Zealand region and Antarctica (Wilkes Land and South Victoria Land, the two doubtless continuous) on the one hand, and South America and Antarctica (Graham Land) on the other. We are quite justified in believing that these epicontinental sea-bottoms were land areas for long periods of time and have since subsided beneath the ocean level.

Here then was the land connection which furnished not only the highway for the interchange of forms of life between the southern continents, but also a vast territory of subpermanent residence and consequent multiple development of those forms during the intervals that elapsed between their successive wanderings. So far as area goes, it was practically as though the continent of Africa were to be laid down on the south polar region today, with its center on the pole. But it would be an Africa well watered throughout, even somewhat increased in size, perhaps not much changed in contour, with very different faunal and floral elements.

Alexander Land is probably a continuation of Graham Land, and King Edward VII Land is an extensive reach that probably connects these with South Victoria Land. On the opposite side, Coats Land and Enderby Land probably meet and form a land reach directly south of Africa, probably also continuing to Graham Land on the one side and to Wilkes Land on the other. Thus we almost certainly have to-day in Antarctica one vast compact land mass forming a continent more than twice the size of Australia, or even larger than South America and almost the counterpart of the latter in outline. There is no such continental mass in the north polar region.

In former ages the elevation of Antarctica above sea level was, as a matter of course, much less than now. Shackleton has found to exist there at present an immense plateau-continent with twice the average altitude of Asia - the highest of the other continents. The upheaval of Antarctica has certainly been going on for ages. During Tertiary times the continent was probably not dissimilar in average elevation to present-day South America and Asia, and its subsequent further uplift- ing during periods of diastrophic activity has been the immediate cause of its present isolation through the subsidence of its shelflines. Probably the Australian-AntarcticSouth American land-connection was maintained from early Paleozoic time to somewhere about the Jurassic period. This is indicated by the present distribution of the muscoid flies in Australia and South America. The writer would like to know whether this view is borne out by a study of other elements of the two faunæ. At all events, it appears that South America was the first to lose its connection wih the southern continental mass.

Africa was also quite certainly connected with Antarctica, and through it with South America and Australia, its connection with the main mass having apparently persisted to a much later date than that of South America, if we may credit the evidence of present muscoid fly distribution in the continents concerned. Comparatively shallow depths must exist somewhere between the African region and Antarctica. The southern extremity of Africa is in latitude $35^{\circ}$ south, and its connection with the southern continental mass implies a land stretch of some 5,000 geographic miles in opposite directions to Australia and South America respectively, along the edges of the south polar region. It is likely that the African connection was maintained by a comparatively narrow isthmus, and until about Miocene times.

Add to Antarctica as above restored the great extents of land area represented by the Paleozoic and Mesozoic continents of South America, Africa and Australia, all continuous, with many high mountain ridges interspersed, all in the main under a mild and equable climate, and we have a vast range of land surface which, in its possibilities for the evolution of varied forms of life, quite staggers the imagination. It is even possible to imagine a land connection of Africa and South America, on the one hand, through Antarctica and Australia, with, on the other hand, Malaysia and the continent of Asia. There has certainly been connection of Malaysia with Australia, and probably with the Asiatic mainland whose original confines were the general 
Himalayan region. The possibilities of the biogeographic vista of remote antiquity opened up to us by the existence of Antarctica are enormous, and quite equal to the task of explaining the many hitherto perplexing problems of bio-distribution present and past.

It remains to establish the existence of the former contacts of Antarctica with the southern continents during times past, and the duration of those several contacts until the last one was severed and the present complete isolation of the continent effected. Such contacts are indicated by a study of the faunæ of to-day. Their former existence may be established by the determination of epicontinental seas, continental platforms and submerged ridges, in and about the regions in question. Their duration may be revealed by a study of the geological history of organisms coupled with that of present-day biogeography. We may look forward with the liveliest interest to the much-to-be-desired paleontologic results which should be forthcoming from the further south polar expeditions now outfitting. Certainly here is the field for fruitful investigation of the phylogeny of late and early forms of life, can one but withstand the rigors of its present climate.

It would now appear that the question of the one-time existence of the fabled continent Gondwana, furnishing an east-and-west connection between South America, Africa and Australia, may be relegated to oblivion; the more decidedly so in view of the quite certainly established permanence throughout geologic time of the present ocean basins. Antarctica is doubtless the real Gondwana, but in another quarter-the southern!

\section{Charles H. T. Townsend}

Prura, Peru, July 4, 1910

\section{THE INFLUENCE OF NUTRITION UPON THE ANIMAL FORM}

THE above-named paper by H. J. Waters, presented at the thirtieth meeting of the Society for the Promotion of Agricultural Science, is reviewed because it appeared in an agricultural publication and may not otherwise come to the attention of the experimental morphologist and others to whom it may be of considerable interest. Mr. Waters reports some experiments that were made at the Agricultural College of the University of Missouri. A number of young beef steers were kept during the growth period on different planes of nutrition. One group were fed so as to allow a gradual increase in weight (supramaintenance); a second group were so fed that they kept a constant weight (maintenance); a third group were fed so that they gradually lost weight (submaintenance). The animals were measured carefully at regular intervals during the experiment. The results show that even in the submaintenance animals the skeleton continues to grow for a long time, but its growth is retarded and after several months checked completely. The point of greatest interest is the disproportionate growth of the skeleton in the underfed animals. The ratio of the total increase in the width of the hips to the total increase in height at the withers during the entire experiment is approximately as follows: in the supramaintenance group, $1: 2$; in the maintenance group, $1: 3$, in the submaintenance group, 1:5. Underfeeding retards the increase in the width of the skeleton at the hips much more than it retards its increase in height. In other words the skeleton of a beef steer grows much wider in proportion to its height when the animal is well fed than when it is poorly fed. The author is inclined to attribute the expansion of the skeleton typically seen in beef cattle to the continuous pressure of the distended alimentary canal.

It is interesting to note that the ancestral type, from which the modern beef animal has been derived, corresponds in the shape of the skeleton to the underfed animals described above. Stockmen have insisted for many years that the best bred beef animals, when kept under range conditions, will assume in a few generations what is commonly known as the "sun-fish" type, or an approximation to the ancestral type. The narrowing of the skeleton in response to an inadequate food supply may be a physiological adaptation, or it may be a case of reversion. E. T. BELL 